\title{
Food Security and COVID-19: A Systematic Review of the First-Year Experience
}

\author{
Boglárka Anna Éliás and Attila Jámbor *(i) \\ Department of Agribusiness, Corvinus University of Budapest, Fővám tér 8, 1093 Budapest, Hungary; \\ boglarka.elias@stud.uni-corvinus.hu \\ * Correspondence: attila.jambor@uni-corvinus.hu
}

Citation: Éliás, B.A.; Jámbor, A. Food Security and COVID-19: A Systematic Review of the First-Year Experience. Sustainability 2021, 13, 5294. https:// doi.org/10.3390/su13095294

Academic Editor: Aitazaz

A. Farooque

Received: 2 April 2021

Accepted: 4 May 2021

Published: 10 May 2021

Publisher's Note: MDPI stays neutral with regard to jurisdictional claims in published maps and institutional affiliations.

Copyright: (C) 2021 by the authors. Licensee MDPI, Basel, Switzerland. This article is an open access article distributed under the terms and conditions of the Creative Commons Attribution (CC BY) license (https:// creativecommons.org/licenses/by/ $4.0 /)$.

\begin{abstract}
For decades, global food security has not been able to address the structural problem of economic access to food, resulting in a recent increase in the number of undernourished people from 2014. In addition, the FAO estimates that the number of undernourished people drastically increased by $82-132$ million people in 2020 due to the COVID-19 pandemic. To alleviate this dramatic growth in food insecurity, it is necessary to understand the nature of the increase in the number of malnourished during the pandemic. In order to address this, we gathered and synthesized food-security-related empirical results from the first year of the pandemic in a systematic review. The vast majority $(78 \%)$ of the 51 included articles reported household food insecurity has increased (access, utilization) and/or disruption to food production (availability) was a result of households having persistently low income and not having an adequate amount of savings. These households could not afford the same quality and/or quantity of food, and a demand shortfall immediately appeared on the producer side. Producers thus had to deal not only with the direct consequences of government measures (disruption in labor flow, lack of demand of the catering sector, etc.) but also with a decline in consumption from low-income households. We conclude that the factor that most negatively affects food security during the COVID-19 pandemic is the same as the deepest structural problem of global food security: low income. Therefore, we argue that there is no need for new global food security objectives, but there is a need for an even stronger emphasis on poverty reduction and raising the wages of low-income households. This structural adjustment is the most fundamental step to recover from the COVID-19 food crises, and to avoid possible future food security crises.
\end{abstract}

Keywords: COVID-19; food security; pandemic; low-income; income loss; vulnerable groups; systematic review; household food security; food production; food price; input shortage

\section{Introduction}

On the 22nd of January in 2020, the mission of the World Health Organization in Wuhan, China confirmed evidence of the first human-to-human infection case of SARSCoV-2 (COVID-19) [1]. In less than two months, on 11th of March, Dr Tedros Adhanom Ghebreyesus, Director-General of the World Health Organization, described the COVID-19 outbreak as a global pandemic [2]. In the following weeks the whole world experienced a rapid global spread of the virus. National governments began to reorganize their healthcare system, ordered lockdowns, curfews, travel and transportation restrictions, and further measures which they considered to be important to slow the spread of infections. Since the outbreak of the pandemic, more than 2.7 million people have lost their life due to COVID-19 infection [3] (according to estimations from the IMF), the global real GDP growth rate dropped by more than seven percent from 2019 to 2020 [4] (a deeper recession than during the financial crisis of 2008-2009) [5], and, simultaneously, the number of undernourished people has possibly increased by between 82 and 132 million in 2020 [6].

This dramatic increase has boosted the devastating trend of the number of undernourished people increasing since 2014, after a decade of decline. In 2019, the estimated number 
of undernourished people reached 687.8 million, an almost 60 million increase compared with 2014 [6]. Note that, in 2019, 13 countries provided new data about population, food supply and the results of household surveys for FAO. One of the 13 countries was China, with around 19 percent of the world's population; consequently, the new data caused a significant change. After the revision of previous estimations, it was found that the number of undernourished people was overestimated by around 150 million people. According to FAO projections, the number of undernourished people will reach 841.4 million by 2030, ceteris paribus. However, this calculation did not take into account the effects of COVID-19, implying significant changes compared with the pre-COVID-19 structural problems of global food security [6].

Several food security concepts exist; we followed the most widespread concept, FAO's concept, which divides the complex food security issues into four clear dimensions: availability, access, utilization, and the stability of the previous three [7]. In addition to the four dimensions, we can also distinguish between structural and temporary food security problems [8]. After the improvement in availability and physical access through producing more than enough food for the global population and developing rural infrastructure in several regions, the global food security focus shifted to the issue of economic access, which is still the deepest structural obstacle to reducing under- and malnutrition. The narrative that economic growth must reach even the poorest has been a constant part of the objectives of the FAO for many years, and data showed that the growth of income inequality increases the likelihood of severe food insecurity [9]. Low income has a negative impact on several layers of food insecurity, it is responsible for hunger, undernourishment (food quantity) and malnutrition (food quality) [6]. Furthermore, adequate income and savings are crucial parts of food consumer resilience [10], which is essential to avoid food shocks during such unexpected negative events as income loss, sickness, environmental disasters, pandemics, etc. In other words, a structural problem of food security is obstructing the effective resolution of a temporary crisis.

Today, we are experiencing a global temporary food security crisis together with the COVID-19 pandemic. Its effect has a strong and complex relationship to pre-existing structural weaknesses. The aim of this paper is to investigate how the COVID-19 pandemic has affected global food security, after one year of the virus outbreak, based on the available empirical results.

As food supply was one of the major concerns at the beginning of the first lockdown, as panic-buying clearly showed, reviews and policy recommendations were published even in the early months of the pandemic on this subject. These papers had crucial importance in supporting decision-making by emphasizing the present challenges and the potential mid- and long-term threats.

The early publications warned that economic access/affordability were threatened from two directions: households were losing their income partially or completely as a result of lockdowns [5,10]; and, at the same time, food prices could increase due to supply shortages caused by transport and travel restrictions $[5,10,11]$ and the retention of cereal exports from major suppliers, such as Russia, Kazakhstan, Vietnam and Cambodia [12]. In parallel with income loss, non-staple food, such as fruits, vegetables and animal protein, became less affordable [5]. Low-income households may be further burdened by the loss of school meals as a result of school closures in many places [5]. In addition to economic access reduction, some physical-access-related problems emerged as well because of movement restrictions [10-13]. The fear of losing physical access to food resulted in panic-buying (food hoarding that caused a short, temporary supply shortage at the beginning of the first wave of the pandemic) and put those who were not fast enough or could not afford buying in large amounts at once in a difficult situation [12,13].

However, there was a consensus in the literature that food access is the most vulnerable dimension; some articles drew attention to potential threats to availability/production. Movement restrictions could cause a decline in demand and disruption in labor and other inputs' supply [10]. Laborde et al. [5] projected that the effect is more severe on low-income 
countries, where farming is more labor-intensive than high-income countries that have widespread large-scale mechanized farming with farmers that are less exposed to infection. Workie et al. [12] outlined a more detailed picture of the possible effects on agriculture in developing countries. According to their claims, supply shortages will hit developing countries to a smaller extent, compared with developed counties, because developing countries are less dependent on material inputs but more dependent on labor, and the labor shortage will cause obstructions in production.

The most negative effects are expected on both the consumer and producer sides in low-income countries, especially in South Asia and sub-Saharan Africa, as many people do not have sufficient savings or available social safety nets; therefore, the greatest decrease in food demand is expected to be in developing countries [5,12].

As mentioned above, these early publications played an important role in supporting policymakers in a situation which the world has not experienced before. However, these papers could only rely on a small number of empirical results, as the availability of evidencebased empirical research results was limited in the first months of the COVID-19 pandemic. One year on from the outbreak of the global pandemic, it is important to gather and systematize the available empirical evidence and compare the initial projections to the experience gained over the past year; the sooner we understand the effects of the COVID-19 pandemic and lockdowns on food security, the better measures taken to mitigate these negative effects in the long term can be.

The available systematic reviews related to this topic were published in the first months of the pandemic $[14,15]$ or limited to a certain country [16], thus, we consider that this systematic review will fill a gap in the analysis of empirical data from a one-year perspective; as far as we know, this will be the first paper to revise global food security objectives in consideration of the effects of the pandemic.

\section{Research Questions}

2.1. Q1. What Segments of Food Security Have Been Affected by the COVID-19 Lockdown and Pandemic?

We aimed to answer this question through empirical evidence from the first year of the global pandemic. This question focusses on food consumers and producers to cover all four food security dimensions.

\subsection{Q2. Are the COVID-19-Related Food Security Problems Temporary and "Crisis Specific" or} Are They Rooted from Structural Weaknesses?

For policymaking, it is crucial to understand whether the experienced drop in food security is temporary and will recover when the pandemic ends, or it is coming from preexisting structural problems which have become even deeper because of the pandemic. In the second case, vaccination and reducing the number of infections is not sufficient-further measures are required.

\subsection{Q3. Are New Food Security Objectives Needed to Mitigate the Negative Effects of the Pandemic and Prepare for a Possible Future Pandemic?}

After answering both research questions above, we compare our claims to the former global food security narrative and assess whether there are new global food security goals emerging from the pandemic.

\section{Materials and Methods}

Our systematic data collection and analysis process was conducted by following the PRISMA (preferred reporting items for systematic reviews and meta-analyses) guidelines [17]. As a first step, we set up our review protocol, a well-defined inclusion, and exclusion criteria and developed our search strategy. The data collection started in October 2020 and we ran our last search in April 2021. During this period, we conducted regular searches and systematized the literature found and kept notes of this process throughout. 


\subsection{Search Strategy: Databases, Keywords}

We used Scopus and Web of Science search engines for our data collection. The fact that vast majority of the journals that are included in the Scopus and Web of Science databases use a strict professional review procedure played a role in choosing these two search engines. First, we used the simple combination of "food security" and covid/coronavirus keywords, but this resulted in some relevant articles being missed, especially in regard to diet; thus, we extended our search with "food choice" and "food access" (Table 1) and limited the result to the years 2020 and 2021.

Table 1. Search keywords.

\begin{tabular}{|c|c|c|c|c|}
\hline "food security" & \multirow{5}{*}{ AND } & \multirow{5}{*}{ covid } & \multirow{5}{*}{ OR } & \multirow{5}{*}{ coronavirus } \\
\hline OR & & & & \\
\hline "food access" & & & & \\
\hline OR & & & & \\
\hline "food choice" & & & & \\
\hline
\end{tabular}

\subsection{Selection}

The PRISMA flow diagram (Figure 1) presents how the number of articles were reduced through the selection procedure.

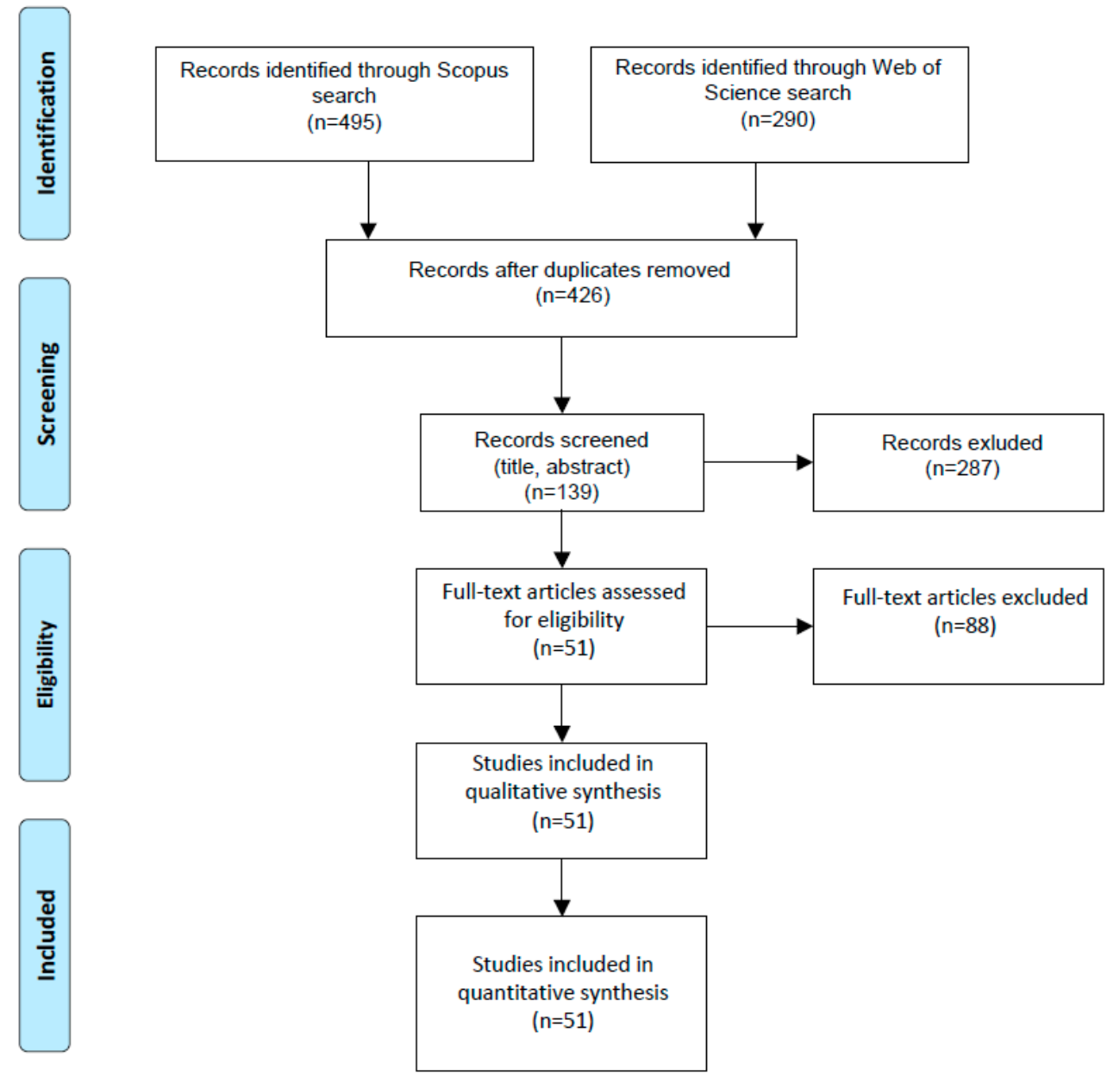

Figure 1. PRISMA flow diagram. Source: own results presented through the PRISMA flow diagram composition of Page et al. [17]. 


\subsubsection{Eligibility Criteria}

The first step of the selection procedure started prior to data collection. In the research protocol, we defined the following eligibility/inclusion criteria:

1. Research article;

2. The article includes original empirical evidence related to COVID-19 effects on food security (from consumer and/or producer side);

3. Quality requirements: transparent data collection, grounded analysis methods, wellargued conclusion.

\subsubsection{Removing Duplicates}

After running multiple searches according to the strategy above, we found and removed 359 duplicates from the results. For detecting the duplicates, we used the Microsoft Word compare function to compare the bibliography list of the results from the two search engines and, by alphabetical sorting, we identified the duplicates within one search engine. This semi-manual semi-mechanical method allowed for fast but thorough filtration.

\subsubsection{Screening}

Through reading the titles and abstracts, we excluded papers which were not related to our subject. Where the abstract provided details about methodology, we screened out reviews, comments and notes. (We did not limit our search to "articles only" because, according to our experience, this function is not always reliable and we did not want to risk excluding a paper that otherwise would meet our requirements.) In the first months of the pandemic, the number of empirical research articles was greatly exceeded by the number of various reviews and policy recommendations, leaving only 139 articles at the end of the screening.

\subsubsection{Eligibility, Inclusion}

We read the full text of the remaining articles and screened out (1) papers which, despite what the abstract suggested, did not include original empirical results and (2) papers that presented empirical results but lacked the quality requirements described above. We found 51 papers that met our eligibility criteria and were suitable for inclusion in qualitative synthesis.

\subsection{Analysis}

Although the quantitative results of the articles-due to the different data collection, sample and analysis methods-were not homogeneous enough for conducting a statistical meta-analysis, it was possible to perform an overview and summary about the researchdesign-related elements of the articles and conduct a qualitative analysis.

\subsubsection{Research-Design-Related Characteristics}

We systematized the articles according to their research design, sample size, time of data collection and place of data collection.

\subsubsection{Qualitative Analysis}

Predefined groups:

Our eligibility criteria determined two groups:

1. GROUP1: consumer/demand/household/access/utilization approach

Food consumers represent the demand on the markets and, in the food security concept they provide the household-level information about the state of food access and utilization.

2. GROUP2: producer/supply/availability approach

Food producers are providing the supply for the consumers, in food security terms their production determines the availability of food. 
As the two groups presented above were part of the inclusion criteria, the articles were already divided into two main groups at the end of the selection process. Then, we coded the articles based on the topics of their findings related to the effects of the COVID-19 pandemic on food security. These codes were not predefined, they were developed from the findings of the articles. We then compared and synthesized our codes, and obtained our final subgroups, which are the following:

Subgroups of GROUP1:

GROUP1.1. INCOME_LOSS

GROUP1.2. VULNERABLE_GROUPS

GROUP1.3. LESS_HEALTHY_DIET

GROUP1.4. POSITIVE_CHANGE

Subgroups of GROUP2:

GROUP2.1. FACTORS_OF_PRODUCTION

GROUP2.2. PRICE

GROUP2.3. OUTPUT

GROUP2.4. TRANSPORT

\section{Results}

\subsection{Research Design}

All of the articles used a descriptive design and the survey data collection method. We assumed that survey design was the most suitable for the pandemic, given circumstances such as social distancing and movement restrictions, as surveys could be easily conducted online, contrary to qualitative data collection methods.

\subsection{Sample Size}

Figure 2 presents the number of articles with different sample sizes. 14 articles worked with data from 100-500 and another 14 with 1000-3000 respondents. The smallest sample size category (less than 100 respondents) was the least common, only three articles had this size of sample.

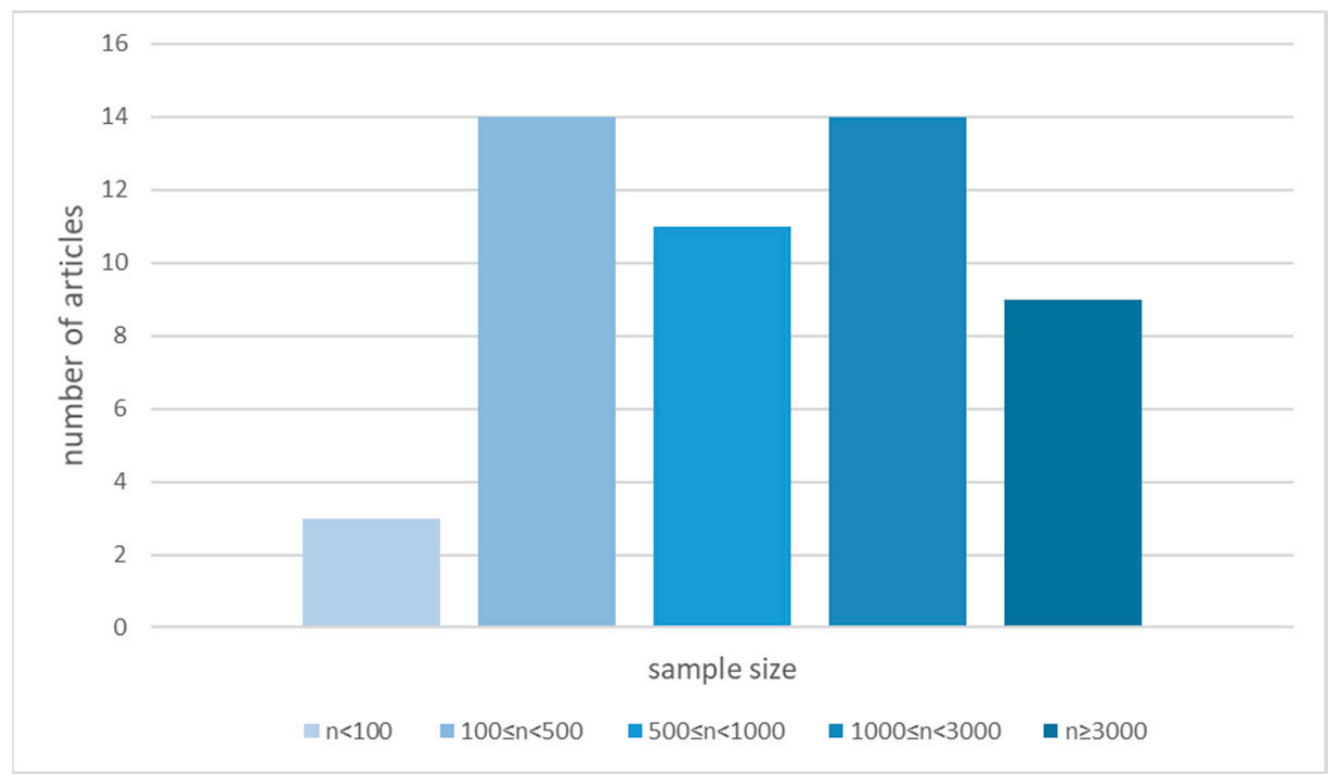

Figure 2. Number of articles by sample size. Source: own calculations. 


\subsection{Time and Place of Collection}

Figure 3 shows how many articles include collected data from certain months. On the figure, more articles appear than we have included in the review in total because if an article's data collection period lasted, for example, from May to July, it appears in each month's column. The articles which were available before April 2021 and used in our review lean on data mostly from the first months—mostly April and May—of the global pandemic.

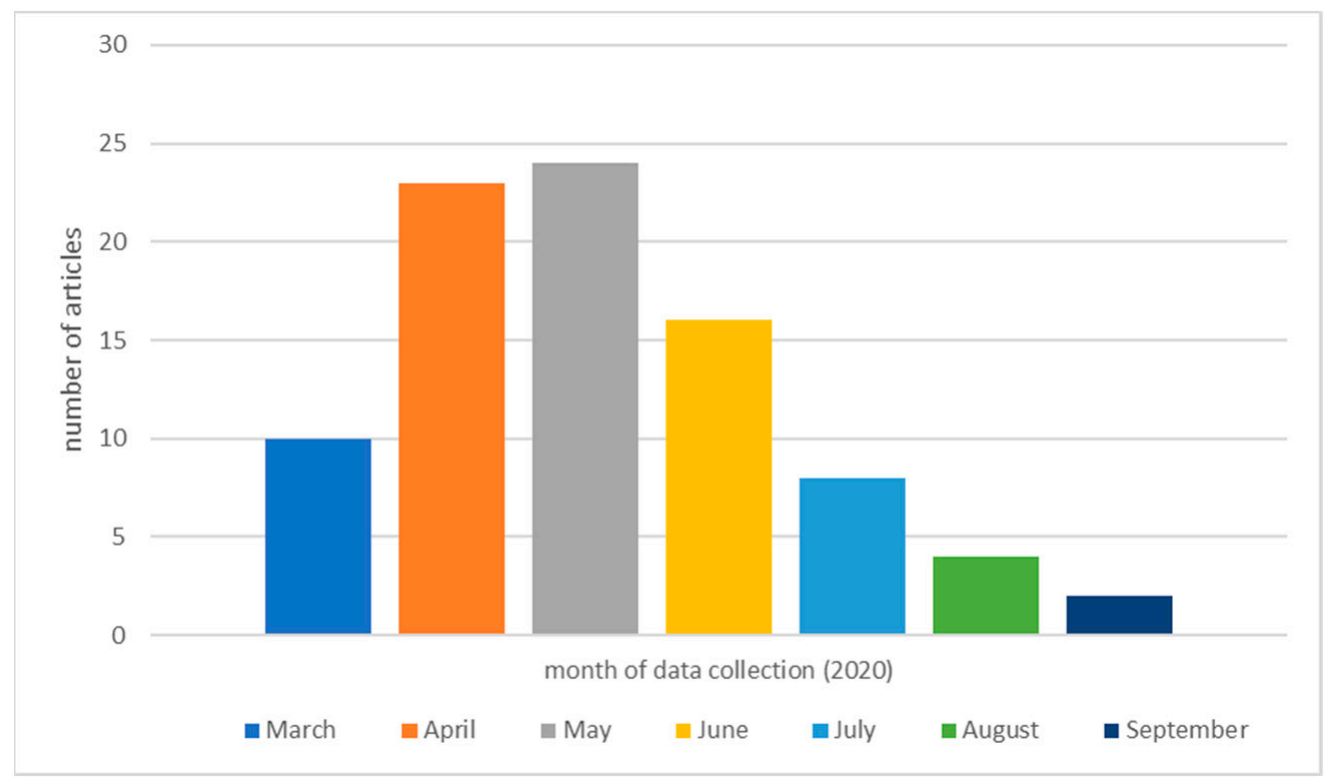

Figure 3. Number of articles by month of data collection. Source: own calculations.

The time of data collection is particularly important in COVID-19-pandemic-related research. There may be large differences between food consumption and production experience of households and producers in periods with high numbers of new COVID-19 cases and lockdowns compared with periods in which restrictions were eased and the number of cases were lower. However, it is important to note that the high number of daily new cases and the introduction of restrictive measures usually (but not necessarily) go hand in hand. We examined the articles one by one to see if the date of data collection took place during a so-called pandemic wave (persistently high daily new cases); for this examination, we used the Worldometers website's coronavirus database which provides data about daily new cases and daily deaths since 15th of February 2020 by countries [18]. We found that this was the case for 45 articles (88.2\%). However, for six articles (11.8\%), data collection was conducted in a period of very low numbers of daily new cases [19-23] or even without daily new cases [24], and problems still arose from both the consumer and producer sides. The reason for this was the introduction of preventive government measures. This finding supports the assumption in the early literature [10] that food security is primarily affected not by the health aspect of the pandemic but by the measures to prevent or mitigate the pandemic.

Table 2 summarizes how many articles collected data from certain countries. Of these articles, $29.4 \%$ present data from the United States, while the second-most-common countries for data collection were India and Kenya9 with 9.8\%. 
Table 2. Number of articles by country of data collection.

\begin{tabular}{cccc}
\hline $\begin{array}{c}\text { Country of Data } \\
\text { Collection }\end{array}$ & Number of Articles & $\begin{array}{c}\text { Country of Data } \\
\text { Collection }\end{array}$ & Number of Articles \\
\hline Australia & 1 & Mexico & 1 \\
Bangladesh & 3 & Mozambique & 1 \\
Brazil & 1 & Myanmar & 1 \\
Burundi & 1 & Nepal & 1 \\
Cameroon & 1 & Peru & 1 \\
Canada & 3 & Poland & 2 \\
China & 1 & Senegal & 1 \\
Congo (DR) & 1 & Slovenia & 1 \\
Denmark & 1 & Spain & 1 \\
France & 1 & Tanzania & 1 \\
Germany & 1 & Uganda & 1 \\
India & 5 & United Kingdom & 2 \\
Iran & 1 & United States & 15 \\
Italy & 2 & Vanuatu & 1 \\
Jordan & 1 & Zambia & 1 \\
Kenya & 5 & Zimbabwe & 1 \\
Malaysia & 2 & & \\
\hline
\end{tabular}

\subsection{Qualitative Results}

\subsubsection{Losing Income}

Many articles in our sample highlighted income loss as one of the most important impacts of COVID-19 on global food security. The extent of income loss and decline in food security varied widely across articles, but each article in this group identified income loss as the main reason (or one of the main reasons) for the drop in food security during the pandemic.

An obvious relationship was observed between income loss and food insecurity. Households who lost their income partially or completely were more likely to experience disruption in their food access [25-28]. Most of the studies collected data on food security only during the lockdown period, however, some articles also provided comparative data on food security before and during lockdowns. Compared to the pre-COVID-19 period, Kansiime et al. [22] reported a 38\% increase in the number of food-insecure households in Kenya and a $44 \%$ increase in Uganda. The same rate was 45\%, according to Kundu et al. [29], while Hamadani et al. [30] reported a 43\% increase in Bangladesh. In Brazil, according to Rocha et al. [31], the prevalence of food insecurity among mothers was $15 \%$ higher between July and September 2020 than it was in 2017.

There are five studies from the United States which provide comparative data on income loss and food insecurity. Each study processed data collected between March and June 2020; however, their surveys targeted different social groups, thus, the results also vary. Patrick et al. [32] reported a 3-4\% increase in food insecurity, while Adams et al. [33] reported $20 \%$. In the article by Dou et al. [34], 30\% more people reported worse food security than before the pandemic, one third of the people were more food insecure according to Niles et al. [35], and $60 \%$ of the respondents of Mialki et al. [36] claimed to be less food secure. In India [37] and Kenya [23], 62\% and 74\% of respondents, respectively, experienced food insecurity related to decreased income. In some cases, in addition to the partial or total income loss, households even had to face rising food prices [20,38]. In order to mitigate income-loss-related food insecurity of households, the most common strategy was launching food or financial benefit programs, mostly by governmental organizations $[31,33,39,40]$, but there were examples of households taking loans or borrowing cash from formal or informal sources [38,39]. Ibrahim and Othman provided information from Malaysia about a third kind of strategy, where $32 \%$ of the respondents started to pick vegetables from the area around their house and $27 \%$ conducted online business [38]. 


\subsubsection{Groups Vulnerable to Food Insecurity}

A significant number of the articles identify the groups most vulnerable to food insecurity. We only assigned articles to this group in which the authors explicitly comment on this issue, we did not draw any conclusions from the samples and quantitative results alone. In most cases, persistently low-income households were identified as a group that proved vulnerable during the pandemic $[19,24,26,29,34,38,40-47]$. The occupation of heads of families was closely linked to low incomes. Unstable and/or low-income jobs also made individuals and families vulnerable $[26,29,44]$. There is evidence from Australia and Bangladesh that living in the countryside is also a vulnerability factor [26,29]. Further factors that play a role in vulnerability include: living with disability [26]; living with dependents [26,40,48]; having fewer male children [44]; travel restrictions [24,47]; distrust in food [47]; farmers having no storage capacity [21]; being a younger [48], especially male [40], adult; relationship status [40,43]; race [43]; and living far from food stores [48].

\subsubsection{Following a Less Healthy Diet}

Various factors played a role in the fact that many people started to follow a less healthy diet during the lockdown. The most common reason was of financial origin. Due to the loss of income and/or the increase in food prices, households could not afford to buy certain foods $[20,22,37,42,49-54]$. Another reason was the change in daily routine due to school closures, working in a home office, movement restrictions, etc. Snacks provided emotional compensation for those who felt bored or lonely $[33,34,50,51,53-58]$. Because of the fear of infection, some people went to buy food less often than their diet would have required [20,49], and in some cases, even if consumers went to buy food, there was a temporary shortage of food or of good quality food [49]. Consumption of non-perishable food, such as canned and frozen foods, increased during the lockdown as well as alcohol consumption [53].

The change in diet meant an increase in the consumption of snacks and processed food $[33,42,52,54,55,58,59]$, a decrease in the consumption of fruits, vegetables $[22,37,49,58]$ as well as meat and fish [20,37]. From Italy, Scacchi et al. [52] reported an increase in vegetable and fruit consumption, but a decrease in fish consumption. As a result of the negative diet shift and decreased exercise, people experienced varying degrees of weight gain $[33,34,59]$.

\subsubsection{Positive Change}

Although the pandemic generally raised concerns and barriers to food security, some empirical studies report positive changes. Harris et al. [37] reported that $15 \%$ of the respondent farmers consumed more vegetables during the lockdown than before, and Larson et al. [42] and Rodríguez-Pérez et al. [60] also found that some of the respondents paid more attention to eating healthier to boost their immunity. Glabska et al. [50] reported that health and weight control became a more important factor during the pandemic than before and, according to Marty et al. [56], weight control intentions improved the quality of diets. There is evidence from Nepal for a reduction in tobacco and alcohol consumption [61]. There are examples of an overall increase in food access [36,44,62]. According to the articles, the reason behind these positive changes in food access could be the initial food gathering [44] and lockdown-related food assistance, as well as other benefits [62].

\subsubsection{Factors of Production}

The articles in this group are based on data collection between April and August 2020. Producers have experienced change in terms of material inputs (seeds, fertilizers), production areas and their workforce.

Two problems have arisen on the material input market: rising input prices and the unavailability of inputs. In India, $60.67 \%$ of the involved shrimp industry stakeholders recognized an input price increase in April [63]; in Zimbabwe, Kenya and Congo (DR) 
this proportion was $31 \%, 22.2 \%$ and $19.5 \%$, respectively [64]. Seed unavailability was especially a significant problem in Mozambique, Congo (DR) and Zimbabwe [64], and also in Senegal [65] and Myanmar, where almost half of the input retailers and crop traders reported disruption in May [66]. The fertilizer market proved to be more stable according to the reviewed articles; the highest proportion of respondents who reported fertilizer unavailability was $14.3 \%$ from Uganda [64].

Of the 504 shrimp industry players in India, 81\% reported a reduction in shrimpfarming area [63].

Due to travel restrictions and the fear of infection, producers faced shortages of labour, which resulted in increased costs of hired labour $[63,64,67]$.

\subsubsection{Decrease in Sales Prices}

Producers from India [37,63,67], Malaysia [68], Peru [69], Kenya, Congo, Tanzania, Uganda, and Zimbabwe [64] could only sell their products at a lower price than previously between April and August in 2020.

\subsubsection{Output}

During the pandemic, as a consequence of disruptions in input supply, planting and harvesting earlier or later than normal was reported from India [67] and, less significantly, from Congo (DR), Zambia and Uganda [64]. Due to the drop of prices, wheat and black gram growers decided to store their harvest for future sale in India [67]. In Kenya, in parallel with the fall of fish consumption, the number of active fishers and the fish stocks decreased in May and June 2020 [20]. In Senegal, more than half of the respondents anticipated their output would decrease by $26-50 \%$ as a result of input shortage [65].

\subsubsection{Transport}

Transport restrictions not only caused a shortage in labour, but also caused disruption in input availability [64] and difficulties or higher prices for reaching markets [67,68].

Table 3 shows how many articles belong to a group or subgroup, and what percentage of the articles can be classified into a certain group or subgroup. Of the articles, 31 belong to only one subgroup, 13 belong to two, three belong to three, and four belong to four subgroups. There are two articles that are included in both groups. The most common combinations of subgroups were INCOME_LOSS + LESS_HEALTHY_DIET and INCOME_LOSS + VULNERABLE_GROUPS with 5-5 articles classified into these subgroups at the same time.

Table 3. Number and percentage of articles belonging to groups and subgroups.

\begin{tabular}{|c|c|c|c|c|c|}
\hline : & $\begin{array}{l}\text { Articles Belong to } \\
\text { the Group (pc) }\end{array}$ & $\begin{array}{l}\text { Articles Belong to } \\
\text { the Group (\%) }\end{array}$ & Subgroup & $\begin{array}{l}\text { Articles Belong to } \\
\text { the Group (pc) }\end{array}$ & $\begin{array}{l}\text { Articles Belong to } \\
\text { the Group (\%) }\end{array}$ \\
\hline \multirow{4}{*}{ 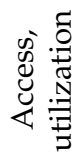 } & \multirow{4}{*}{44} & \multirow{4}{*}{$86 \%$} & Losing income & 19 & $37 \%$ \\
\hline & & & Vulnerable groups & 16 & $31 \%$ \\
\hline & & & Following less healthy diet & 17 & $33 \%$ \\
\hline & & & Positive change & 9 & $18 \%$ \\
\hline \multirow{4}{*}{ 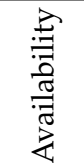 } & \multirow{4}{*}{9} & \multirow{4}{*}{$18 \%$} & Factors of production & 5 & $10 \%$ \\
\hline & & & Price & 7 & $14 \%$ \\
\hline & & & Output & 4 & $8 \%$ \\
\hline & & & Transport & 3 & $6 \%$ \\
\hline
\end{tabular}

Source: own composition.

Table 4 summarizes the articles included in our review by group and subgroup, while Table 5 provides a list of the articles in alphabetical order with the subgroups (and groups) they belong to. 
Table 4. Groups and subgroups and the associated articles.

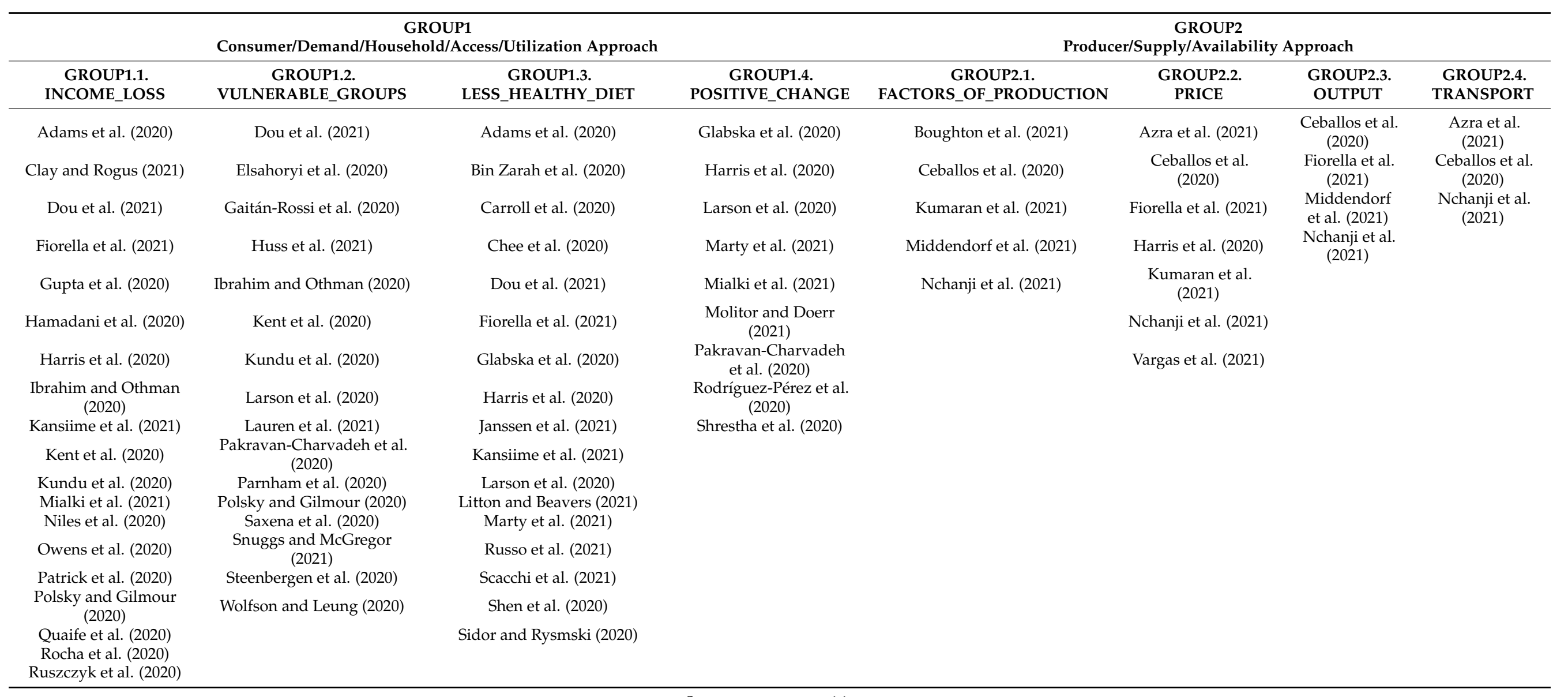


Table 5. Articles and the subgroups they belong to.

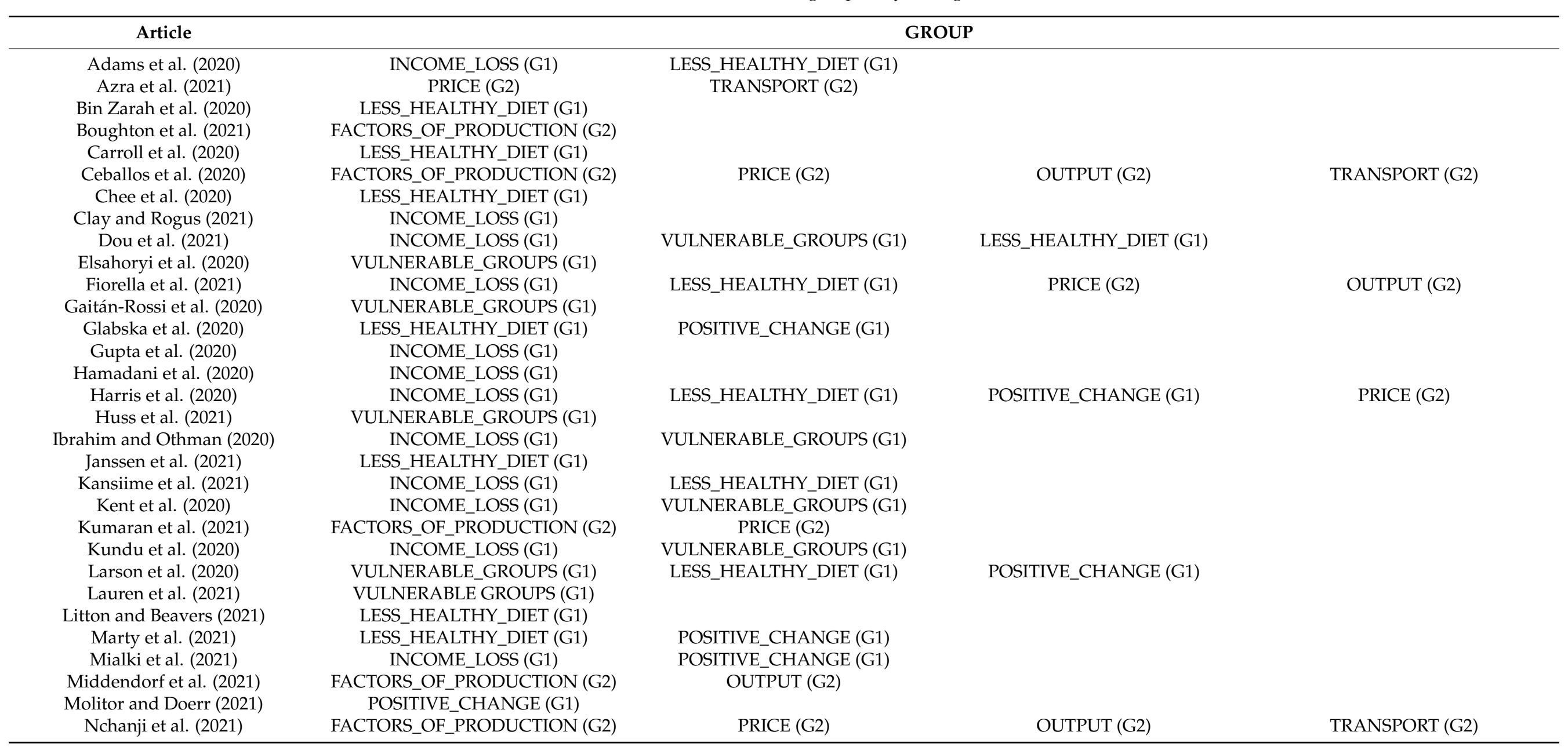


Table 5. Cont.

\begin{tabular}{|c|c|c|}
\hline Article & & GROUP \\
\hline Niles et al. (2020) & INCOME_LOSS (G1) & \\
\hline Owens et al. (2020) & INCOME_LOSS (G1) & \\
\hline Pakravan-Charvadeh et al. (2020) & VULNERABLE GROUPS (G1) & POSITIVE_CHANGE (G1) \\
\hline Patrick et al. (2020) & INCOME_LOSS (G1) & \\
\hline Polsky and Gilmour (2020) & INCOME_LOSS (G1) & VULNERABLE_GROUPS (G1) \\
\hline Quaife et al. (2020) & INCOME_LOSS (G1) & \\
\hline Rodríguez-Pérez et al. (2020) & POSITIVE_CHANGE (G1) & \\
\hline Russo et al. (2021) & LESS_HEALTHYY_DIET (G1) & \\
\hline Ruszczyk et al. (2020) & INCOME_LOSS (G1) & \\
\hline Saxena et al. (2020) & VULNERABLE GROUPS (G1) & \\
\hline Scacchi et al. (2021) & LESS_HEALTHY_DIET (G1) & \\
\hline Shrestha et al. (2020) & POSITIVE_CHANGE (G1) & \\
\hline Shen et al. (2020) & LESS_HEALTTHY_DIET (G1) & \\
\hline Sidor and Rysmski (2020) & LESS_HEALTHY_DIET (G1) & \\
\hline Snuggs and McGregor (2021) & VULNERABLE GROUPS (G1) & \\
\hline Steenbergen et al. (2020) & VULNERABLE GROUPS (G1) & \\
\hline Wolfson and Leung (2020) & VULNERABLE GROUPS (G1) & \\
\hline
\end{tabular}




\section{Discussion and Conclusions}

\subsection{Q1. What Segments of Food Security Have Been Affected by the COVID-19 Lockdown and Pandemic?}

The reviewed empirical results prove that each of the four dimensions/pillars of food security have been affected by the pandemic and lockdowns, though to a different extent. Our findings are mostly consistent with the claims of the early literature. The empirical evidence from the last year confirmed the statement of Laborde et al. [5] and Béné et al. [10] that, during the pandemic and lockdowns, the most vulnerable food security dimension is access; more precisely, economic access. The vast majority of the reviewed papers name financial issues as the primary reason for experiencing food insecurity during the pandemic. The most important financial issues included belonging to a persistently low-income household, losing income partially or completely, or experiencing food price increases. The most vulnerable were those who had to cope with a combination of these factors. Although our sample is not representative in terms of low-, middle- and high-income countries, our results indirectly confirm the assumption of FAO and Laborde et al. [5,9] that low-income countries are affected the most by food insecurity during the COVID-19 crisis, because of their large low-income population.

In addition to the effects on economic access, in some cases, disruption to physical access occurred and caused temporary food insecurity. We add to the literature that physical access was not only disrupted by restrictions on movement [10,13], but also fear of infection, which resulted in some consumers not leaving their homes or visiting supermarkets.

The early literature warned about the following potential threats in food production: decline in demand and disruption in labor and input supply [10]. Each of these presumptions were proved through our results. Decline in demand and sale prices were reported and, simultaneously, disruption in availability of workforces and inputs resulted in higher costs for labor and other material inputs, travel and transport restrictions also caused further costs by increasing the price of reaching markets. Based on our findings, we have no reason to assume that the pandemic would have caused a major drop in production, but it did affect the time of harvest or, due to low prices, forced farmers to store their products. The contradictory assumptions of Laborde et al. [5] and Workie et al. [12] about the agriculture of developing countries being more or less exposed to the effects of the pandemic cannot be judged through our systematic review-a large-scale data analysis would provide more details.

Several articles provided results about a negative shift in diet. In accordance with the literature [5], in the articles included in our review, the most frequently mentioned reason for following less healthy diet was affordability. Another significant reason was also outlined in our review: emotional and psychological needs to cope with the fear of infection and losing social ties, which often resulted in eating snacks or processed food for temporary comfort. Consumption of vegetables, fruits and animal proteins declined the most. Obesity concerns also emerged in some cases. Positive changes in diet due to the pandemic were also reported. In order to boost immunity or control their weight, some people started to follow a more conscious diet.

\subsection{Q2. Are the COVID-19-Related Emerging Food Security Problems Temporary and "Crisis Specific" or Are They Rooted in Structural Weaknesses?}

All the changes in food security reported in this review were triggered by events which are strongly linked to the COVID-19 pandemic and lockdowns. Some of the effects are due solely to the circumstances caused by the pandemic, are of a temporary nature, and will return to pre-pandemic conditions once the number of cases is reduced and restrictions are lifted. Such an effect is, for example, limited physical access due to stock shortages after panic-buying, movement restrictions, or fear of infection. Negative dietary changes caused by anxiety and loneliness are also likely to recover once social connections can be revived. For the producer side, access to markets and the free movement of labor can also be resolved as soon as restrictions are lifted. 
However, consistent with the literature, the largest problem suggested by our results was shown to be low household incomes. Low-income households do not have sufficient savings to bridge the loss of income for up to several months, or are unable to buy in large amounts, and are burdened by suddenly rising food prices. As a result, they cannot afford the same amount of vegetables, fruits, or animal proteins and consume less of these foods; this lack of demand is immediately apparent on the producer side. Producers thus have to deal not only with the direct consequences of government measures, such as the stagnation of labor flows and the lack of demand resulting from the closure of the catering sector, but also with the decline in consumption by low-income households.

Consequently, we conclude that the factor that most negatively affects food security during the COVID-19 pandemic is the same as the deepest structural problem of global food security: low income.

\subsection{Q3. Are New Food Security Objectives Needed to Mitigate the Negative Effects of the Pandemic and Prepare for a Possible Future Pandemic?}

As economic access has proven to be the strongest factor in food security vulnerability during the pandemic, we argue that there is no need for new global food security objectives, but there is a need for an even stronger emphasis on poverty reduction and raising the wages of low-income households so that policymakers understand that this is the first and most essential step in preparing for future crises, as the pandemic highlighted that securing economic access through adequate wages not only increases overall food security in normal times but, in line with Béné's claim [10], is an essential element of householdlevel resilience in the event of a health, economic, or food crisis. By drawing lessons from the COVID-19 pandemic, it will be possible to prepare for temporary disruptions in a similar crisis situation, but there may also be unexpected and novel problems in a crisis, as is the case with COVID-19. It is not possible to prepare for these situations in a targeted way, but improving structural weaknesses, such as financial insecurity, would reduce the negative effects of a crisis on food security to a broader extent.

Although our sample is rather small and not representative, the numbers are indicative that, if we exclude articles that report new food security problems that could have been avoided by consumers having adequate wages and sufficient savings, only 11 of $51,22 \%$ of the articles would remain in our sample. Last but not least, the structural adjustment of poverty and low wages could reduce the financial burden on governments in times of crises, as only a smaller proportion of the population would need food aid or other benefits, leaving more resources to address temporary problems and post-crisis recovery.

Author Contributions: Conceptualization, B.A.É. and A.J.; methodology, B.A.É.; software, B.A.É.; validation, A.J.; formal analysis, B.A.É.; investigation, B.A.É.; resources, A.J.; data curation, B.A.É.; writing—original draft preparation, B.A.É; writing—review and editing, A.J.; visualization, B.A.É.; supervision, A.J.; project administration, A.J.; funding acquisition, A.J. All authors have read and agreed to the published version of the manuscript.

Funding: This research received no external funding.

Institutional Review Board Statement: Not applicable.

Informed Consent Statement: Not applicable.

Data Availability Statement: Data sharing not applicable.

Conflicts of Interest: The authors declare no conflict of interest.

\section{References}

1. WHO. Mission Summary: WHO Field Visit to Wuhan, China 20-21 January 2020. Available online: https://www.who.int/china/ news / detail/22-01-2020-field-visit-wuhan-china-jan-2020 (accessed on 11 March 2021).

2. WHO. Director-General's Opening Remarks at the Mission Briefing on COVID-19-12 March 2020. Available online: https: / / www.who.int/director-general/speeches/detail/who-director-general-s-opening-remarks-at-the-media-briefing-oncovid-19---11-march-2020 (accessed on 11 March 2021). 
3. Worldometers. COVID-19 Coronavirus Pandemic. Available online: https://www.worldometers.info/coronavirus / (accessed on 25 March 2021).

4. IMF. World Economic Outlook, October 2020: A Long and Difficult Ascent. Available online: https://www.imf.org/en/ Publications/WEO/Issues/2020/09/30/world-economic-outlook-october-2020 (accessed on 25 March 2021).

5. Laborde, D.; Martin, W.; Swinnen, J.; Vos, R. COVID-19 Risks to Global Food Security. Science 2020, 369, 500-502. [CrossRef] [PubMed]

6. FAO. The State of Food Security and Nutrition in the World 2020. Available online: http://www.fao.org/publications/sofi/en/ (accessed on 20 March 2021).

7. FAO. Declaration of the World Summit on Food Security. World Summit on Food Security. Rome, 16-18 November 2009. Available online: http://www.fao.org/fileadmin/templates/wsfs/Summit/Docs/Final_Declaration/WSFS09_Declaration.pdf (accessed on 25 March 2021).

8. World Bank. Poverty and Hunger: Issues and Options for Food Security in Developing Countries; World Bank: Washington, DC, USA, 1986; Available online: http:/ / documents1.worldbank.org/curated/en/166331467990005748/pdf/multi-page.pdf (accessed on 20 March 2021).

9. FAO. The State of Food Security and Nutrition in the World 2019. Available online: http://www.fao.org/publications/sofi/2019 /en/ (accessed on 20 March 2021).

10. Béné, C. Resilience of Local Food Systems and Links to Food Security-A Review of Some Important Concepts in the Context of COVID-19 and Other Shocks. Food Sec. 2020, 12, 805-822. [CrossRef] [PubMed]

11. Devereux, S.; Béné, C.; Hoddinott, J. Conceptualising COVID-19's Impacts on Household Food Security. Food Sec. 2020, 12, 769-772. [CrossRef]

12. Workie, E.; Mackolil, J.; Nyika, J.; Ramadas, S. Deciphering the Impact of COVID-19 Pandemic on Food Security, Agriculture, and Livelihoods: A Review of the Evidence from Developing Countries. Curr. Res. Environ. Sustain. 2020, 2, 100014. [CrossRef]

13. Naja, F; Hamadeh, R. Nutrition amid the COVID-19 Pandemic: A Multi-Level Framework for Action. Eur. J. Clin. Nutr. 2020, 74, 1117-1121. [CrossRef] [PubMed]

14. Jámbor, A.; Czine, P.; Balogh, P. The Impact of the Coronavirus on Agriculture: First Evidence Based on Global Newspapers. Sustainability 2020, 12, 4535. [CrossRef]

15. Rahman, S.; Hossain, I.; Rahman Mullick, A.; Khan, M.H. Food Security and the Coronavirus Disease 2019 (COVID-19): A Systemic Review. J. Med. Sci. Clin. Res. 2020, 8, 180-184. [CrossRef]

16. Sereenonchai, S.; Arunrat, N. Understanding Food Security Behaviors during the COVID-19 Pandemic in Thailand: A Review. Agronomy 2021, 11, 497. [CrossRef]

17. Page, M.J.; McKenzie, J.E.; Bossuyt, P.M.; Boutron, I.; Hoffmann, T.C.; Mulrow, C.D.; Shamseer, L.; Tetzlaff, J.M.; Akl, E.A.; Brennan, S.E.; et al. The PRISMA 2020 Statement: An Updated Guideline for Reporting Systematic Reviews. PLoS Med. 2021, 18, e1003583. [CrossRef]

18. Worldometers. COVID-19 Coronavirus Pandemic. Available online: https://www.worldometers.info/coronavirus/worldwidegraphs / (accessed on 21 April 2021).

19. Elsahoryi, N.; Al-Sayyed, H.; Odeh, M.; McGrattan, A.; Hammad, F. Effect of Covid-19 on Food Security: A Cross-Sectional Survey. Clin. Nutr. ESPEN 2020, 40, 171-178. [CrossRef]

20. Fiorella, K.J.; Bageant, E.R.; Mojica, L.; Obuya, J.A.; Ochieng, J.; Olela, P.; Otuo, P.W.; Onyango, H.O.; Aura, C.M.; Okronipa, H. Small-Scale Fishing Households Facing COVID-19: The Case of Lake Victoria, Kenya. Fish. Res. 2021, 237, 105856. [CrossRef]

21. Huss, M.; Brander, M.; Kassie, M.; Ehlert, U.; Bernauer, T. Improved storage mitigates vulnerability to food-supply shocks in smallholder agriculture during the COVID-19 pandemic. Glob. Food Secur. 2021, 28, 100468. [CrossRef]

22. Kansiime, M.K.; Tambo, J.A.; Mugambi, I.; Bundi, M.; Kara, A.; Owuor, C. COVID-19 Implications on Household Income and Food Security in Kenya and Uganda: Findings from a Rapid Assessment. World Dev. 2021, 137, 105199. [CrossRef] [PubMed]

23. Quaife, M.; Van Zandvoort, K.; Gimma, A.; Shah, K.; McCreesh, N.; Prem, K.; Barasa, E.; Mwanga, D.; Kangwana, B.; Pinchoff, J.; et al. The Impact of COVID-19 Control Measures on Social Contacts and Transmission in Kenyan Informal Settlements. BMC Med. 2020, 18, 316. [CrossRef]

24. Steenbergen, D.J.; Neihapi, P.T.; Koran, D.; Sami, A.; Malverus, V.; Ephraim, R.; Andrew, N. COVID-19 Restrictions amidst Cyclones and Volcanoes: A Rapid Assessment of Early Impacts on Livelihoods and Food Security in Coastal Communities in Vanuatu. Mar. Policy 2020, 121. [CrossRef] [PubMed]

25. Clay, L.A.; Rogus, S. Impact of Employment, Essential Work, and Risk Factors on Food Access during the COVID-19 Pandemic in New York State. Int. J. Environ. Res. Public Health 2021, 18, 1451. [CrossRef] [PubMed]

26. Kent, K.; Murray, S.; Penrose, B.; Auckland, S.; Visentin, D.; Godrich, S.; Lester, E. Prevalence and Socio-Demographic Predictors of Food Insecurity in Australia during the COVID-19 Pandemic. Nutrients 2020, 12, 2682. [CrossRef] [PubMed]

27. Owens, M.R.; Brito-Silva, F.; Kirkland, T.; Moore, C.E.; Davis, K.E.; Patterson, M.A.; Miketinas, D.C.; Tucker, W.J. Prevalence and Social Determinants of Food Insecurity among College Students during the COVID-19 Pandemic. Nutrients 2020, 12, 2515. [CrossRef]

28. Ruszczyk, H.A.; Rahman, M.F.; Bracken, L.J.; Sudha, S. Contextualizing the COVID-19 Pandemic's Impact on Food Security in Two Small Cities in Bangladesh. Environ. Urban. 2020. [CrossRef] 
29. Kundu, S.; Banna, M.H.A.; Sayeed, A.; Sultana, M.S.; Brazendale, K.; Harris, J.; Mandal, M.; Jahan, I.; Abid, M.T.; Khan, M.S.I. Determinants of Household Food Security and Dietary Diversity during the COVID-19 Pandemic in Bangladesh. Public Health Nutr. 2020. [CrossRef]

30. Hamadani, J.D.; Hasan, M.I.; Baldi, A.J.; Hossain, S.J.; Shiraji, S.; Bhuiyan, M.S.A.; Mehrin, S.F.; Fisher, J.; Tofail, F.; Tipu, S.M.M.U.; et al. Immediate Impact of Stay-at-Home Orders to Control COVID-19 Transmission on Socioeconomic Conditions, Food Insecurity, Mental Health, and Intimate Partner Violence in Bangladeshi Women and Their Families: An Interrupted Time Series. Lancet Glob. Health 2020, 8, e1380-e1389. [CrossRef]

31. Rocha, H.A.L.; Sudfeld, C.R.; Leite, Á.J.M.; Rocha, S.G.M.O.; Machado, M.M.T.; Campos, J.S.; Silva, A.C.; Correia, L.L. COVID-19, Food Security and Maternal Mental Health in Ceará, Brazil: A Repeated Cross-Sectional Survey. Public Health Nutr. 2021, 1-12. [CrossRef]

32. Patrick, S.W.; Henkhaus, L.E.; Zickafoose, J.S.; Lovell, K.; Halvorson, A.; Loch, S.; Letterie, M.; Davis, M.M. Well-Being of Parents and Children during the COVID-19 Pandemic: A National Survey. Pediatrics 2020, 146, e2020016824. [CrossRef]

33. Adams, E.L.; Caccavale, L.J.; Smith, D.; Bean, M.K. Food Insecurity, the Home Food Environment, and Parent Feeding Practices in the Era of COVID-19. Obesity 2020, 28, 2056-2063. [CrossRef] [PubMed]

34. Dou, Z.; Stefanovski, D.; Galligan, D.; Lindem, M.; Rozin, P.; Chen, T.; Chao, A.M. Household food dynamics and food system resilience amid the COVID-19 pandemic: A cross-national comparison of China and the United States. Front. Sustain. Food Syst. 2021, 4, 577153. [CrossRef]

35. Niles, M.T.; Bertmann, F.; Belarmino, E.H.; Wentworth, T.; Biehl, E.; Neff, R. The Early Food Insecurity Impacts of COVID-19. Nutrients 2020, 12, 2096. [CrossRef]

36. Mialki, K.; House, L.A.; Mathews, A.E.; Shelnutt, K.P. Covid-19 and College Students: Food Security Status before and after the Onset of a Pandemic. Nutrients 2021, 13, 628. [CrossRef] [PubMed]

37. Harris, J.; Depenbusch, L.; Pal, A.A.; Nair, R.M.; Ramasamy, S. Food System Disruption: Initial Livelihood and Dietary Effects of COVID-19 on Vegetable Producers in India. Food Secur. 2020, 12, 841-851. [CrossRef] [PubMed]

38. Ibrahim, A.Z.; Othman, Z. Covid-19: Coping Strategies among B40 Households in Malaysia to Achieve Food Security during Movement Control Order (MCO). Eur. J. Mol. Clin. Med. 2020, 7, 1513-1524.

39. Gupta, A.; Zhu, H.; Doan, M.K.; Michuda, A.; Majumder, B. Economic Impacts of the COVID-19 Lockdown in a RemittanceDependent Region. Am. J. Agric. Econ. 2020, 103, 466-485. [CrossRef]

40. Polsky, J.Y.; Gilmour, H. Food Insecurity and Mental Health during the COVID-19 Pandemic. Health Rep. 2020, 31, 3-11. [CrossRef]

41. Gaitán-Rossi, P.; Vilar-Compte, M.; Teruel, G.; Pérez-Escamilla, R. Food Insecurity Measurement and Prevalence Estimates during the COVID-19 Pandemic in a Repeated Cross-Sectional Survey in Mexico. Public Health Nutr. 2021, 24, 412-421. [CrossRef]

42. Larson, N.; Slaughter-Acey, J.; Alexander, T.; Berge, J.; Harnack, L.; Neumark-Sztainer, D. Emerging Adults' Intersecting Experiences of Food Insecurity, Unsafe Neighbourhoods and Discrimination during the Coronavirus Disease 2019 (COVID-19) Outbreak. Public Health Nutr. 2021, 24, 519-530. [CrossRef] [PubMed]

43. Lauren, B.N.; Silver, E.R.; Faye, A.S.; Rogers, A.M.; Woo Baidal, J.A.; Ozanne, E.M.; Hur, C. Predictors of Households at Risk for Food Insecurity in the United States during the COVID-19 Pandemic. Public Health Nutr. 2021. [CrossRef]

44. Pakravan-Charvadeh, M.R.; Mohammadi-Nasrabadi, F.; Gholamrezai, S.; Vatanparast, H.; Flora, C.; Nabavi-Pelesaraei, A. The Short-Term Effects of COVID-19 Outbreak on Dietary Diversity and Food Security Status of Iranian Households (A Case Study in Tehran Province). J. Clean. Prod. 2021, 281, 124537. [CrossRef] [PubMed]

45. Parnham, J.C.; Laverty, A.A.; Majeed, A.; Vamos, E.P. Half of Children Entitled to Free School Meals Did Not Have Access to the Scheme during COVID-19 Lockdown in the UK. Public Health 2020, 187, 161-164. [CrossRef]

46. Saxena, A.; Amin, A.; Mohan, S.B.; Mohan, P. Food Insecurity in Tribal High Migration Communities in Rajasthan, India. Food Nutr. Bull. 2020, 41, 513-518. [CrossRef]

47. Wolfson, J.A.; Leung, C.W. Food Insecurity and COVID-19: Disparities in Early Effects for Us Adults. Nutrients 2020, $12,1648$. [CrossRef] [PubMed]

48. Snuggs, S.; McGregor, S. Food \& Meal Decision Making in Lockdown: How and Who Has Covid-19 Affected? Food Qual. Prefer. 2021, 89, 104145:1-104145:6. [CrossRef]

49. Litton, M.M.; Beavers, A.W. The Relationship between Food Security Status and Fruit and Vegetable Intake during the Covid-19 Pandemic. Nutrients 2021, 13, 712. [CrossRef]

50. Głabska, D.; Skolmowska, D.; Guzek, D. Population-Based Study of the Changes in the Food Choice Determinants of Secondary School Students: Polish Adolescents' COVID-19 Experience (Place-19) Study. Nutrients 2020, 12, 2640. [CrossRef]

51. Shen, W.; Long, L.M.; Shih, C.-H.; Ludy, M.-J. A Humanities-Based Explanation for the Effects of Emotional Eating and Perceived Stress on Food Choice Motives during the COVID-19 Pandemic. Nutrients 2020, 12, 2712. [CrossRef] [PubMed]

52. Scacchi, A.; Catozzi, D.; Boietti, E.; Bert, F.; Siliquini, R. COVID-19 Lockdown and Self-Perceived Changes of Food Choice, Waste, Impulse Buying and Their Determinants in Italy: Quaranteat, a Cross-Sectional Study. Foods 2021, 10, 306. [CrossRef] [PubMed]

53. Janssen, M.; Chang, B.P.I.; Hristov, H.; Pravst, I.; Profeta, A.; Millard, J. Changes in Food Consumption During the COVID-19 Pandemic: Analysis of Consumer Survey Data From the First Lockdown Period in Denmark, Germany, and Slovenia. Front. Nutr. 2021, 8, 635859. [CrossRef]

54. Chee, M.J.; Koziel Ly, N.K.; Anisman, H.; Matheson, K. Piece of Cake: Coping with COVID-19. Nutrients 2020, 12, 3803. [CrossRef] 
55. Carroll, N.; Sadowski, A.; Laila, A.; Hruska, V.; Nixon, M.; Ma, D.W.L.; Haines, J. The Impact of Covid-19 on Health Behavior, Stress, Financial and Food Security among Middle to High Income Canadian Families with Young Children. Nutrients 2020, 12, 2352. [CrossRef]

56. Marty, L.; de Lauzon-Guillain, B.; Labesse, M.; Nicklaus, S. Food Choice Motives and the Nutritional Quality of Diet during the COVID-19 Lockdown in France. Appetite 2021, 157, 105005:1-105005:7. [CrossRef]

57. Russo, C.; Simeone, M.; Demartini, E.; Marescotti, M.E.; Gaviglio, A. Psychological Pressure and Changes in Food Consumption: The Effect of COVID-19 Crisis. Heliyon 2021, 7, e06607. [CrossRef]

58. Bin Zarah, A.; Enriquez-Marulanda, J.; Andrade, J.M. Relationship between Dietary Habits, Food Attitudes and Food Security Status among Adults Living within the United States Three Months Post-Mandated Quarantine: A Cross-Sectional Study. Nutrients 2020, 12, 3468. [CrossRef]

59. Sidor, A.; Rzymski, P. Dietary Choices and Habits during COVID-19 Lockdown: Experience from Poland. Nutrients 2020, 12, 1657. [CrossRef]

60. Rodríguez-Pérez, C.; Molina-Montes, E.; Verardo, V.; Artacho, R.; García-Villanova, B.; Guerra-Hernández, E.J.; Ruíz-López, M.D. Changes in Dietary Behaviours during the COVID-19 Outbreak Confinement in the Spanish COVIDiet Study. Nutrients 2020, 12, 1730. [CrossRef]

61. Shrestha, C.; Acharya, S.; Sharma, R.; Khanal, R.; Joshi, J.; Ghimire, C.; Bhandari, P.; Agrawal, A. Changes and Compromises in Health Choices during COVID-19 Lockdown in Kathmandu Valley: A Descriptive Cross-Sectional Study. J. Nepal Med. Assoc. 2020, 58, 1046-1051. [CrossRef]

62. Molitor, F.; Doerr, C. Very Low Food Security Among Low-Income Households with Children in California Before and Shortly After the Economic Downturn From COVID-19. Prev. Chronic Dis. 2021, 18, 200517. [CrossRef]

63. Kumaran, M.; Geetha, R.; Antony, J.; Vasagam, K.P.K.; Anand, P.R.; Ravisankar, T.; Angel, J.R.J.; De, D.; Muralidhar, M.; Patil, P.K.; et al. Prospective Impact of Corona Virus Disease (COVID-19) Related Lockdown on Shrimp Aquaculture Sector in India-a Sectoral Assessment. Aquaculture 2021, 531, 735922. [CrossRef]

64. Nchanji, E.B.; Lutomia, C.K.; Chirwa, R.; Templer, N.; Rubyogo, J.C.; Onyango, P. Immediate impacts of COVID-19 pandemic on bean value chain in selected countries in Sub-Saharan Africa. Agric. Syst. 2021, 188, 103034. [CrossRef] [PubMed]

65. Middendorf, B.J.; Faye, A.; Middendorf, G.; Stewart, Z.P.; Jha, P.K.; Prasad, P.V.V. Smallholder Farmer Perceptions about the Impact of COVID-19 on Agriculture and Livelihoods in Senegal. Agric. Syst. 2021, 190. [CrossRef]

66. Boughton, D.; Goeb, J.; Lambrecht, I.; Headey, D.; Takeshima, H.; Mahrt, K.; Masias, I.; Goudet, S.; Ragasa, C.; Maredia, M.K.; et al. Impacts of COVID-19 on Agricultural Production and Food Systems in Late Transforming Southeast Asia: The Case of Myanmar. Agric. Syst. 2021, 188, 103026. [CrossRef]

67. Ceballos, F.; Kannan, S.; Kramer, B. Impacts of a National Lockdown on Smallholder Farmers' Income and Food Security: Empirical Evidence from Two States in India. World Dev. 2020, 136, 105069. [CrossRef]

68. Azra, M.N.; Kasan, N.A.; Othman, R.; Noor, G.A.G.R.; Mazelan, S.; Jamari, Z.B.; Sarà, G.; Ikhwanuddin, M. Impact of COVID-19 on Aquaculture Sector in Malaysia: Findings from the First National Survey. Aquac. Rep. 2021, 19, 100568. [CrossRef]

69. Vargas, R.; Fonseca, C.; Hareau, G.; Ordinola, M.; Pradel, W.; Robiglio, V.; Suarez, V. Health Crisis and Quarantine Measures in Peru: Effects on Livelihoods of Coffee and Potato Farmers. Agric Syst. 2021, 187, 103033. [CrossRef] 